\title{
FAKTOR-FAKTOR PENGHAMBAT AKSEPTOR KB DALAM MENENTUKAN PILIHAN TERHADAP PENGGUNAAN ALAT KONTRASEPSI IUD
}

\author{
Tetty Rihardini, SST \\ Prodi D-III Kebidanan Universitas PGRI Adi Buana Surabaya \\ tettyrihardini@gmail.com
}

\begin{abstract}
ABSTRAK
Membicarakan masalah kualitas "Sumber Daya Manusia" tidak terlepas perencanaan keluarga melalui gerakan Keluarga Berencana untuk mencapai kesejahteraan keluarga. Gerakan KB Nasional selama ini telah berhasil mendorong peningkatan peran serta masyarakat dalam membangun keluarga kecil yang semakin mandiri. Salah satu masalah utama pada penggunaan KB yaitu masih rendahnya penggunaan KB IUD, sedangkan kecenderungan penggunaan jenis KB hormonal seperti pil dan suntik jumlahnya terus meningkat tajam. Rendahnya penggunaan KB IUD ini disebabkan kurangnya dukungan dari tokoh masyarakat, status ekonomi yang relatif rendah, pengetahuan mengenai alat kontrasepsi yang kurang.

Jenis penelitian ini diskriptif dengan populasi seluruh akseptor KB di desa kepunten pada bulan juli s/d agustus 2011 sebanyak 45 akseptor. Pengambilan sampel dengan quota sampling. Instrument penelitian menggunakan kuesioner serta lembar observasi.

Berdasarkan penelitian hasil penelitian diperoleh bahwa yang menghambat akseptor KB memilih IUD adalah biaya (60\%), dukungan suami (57\%), pemahaman terhadap IUD (57\%), jumlah anak (10\%), takut terhadap alat-alat pemasangan IUD (80\%) dan pemasangan IUD (100\%)
\end{abstract}

Kata Kunci : Akseptor KB, IUD

PENDAHULUAN

Gerakan KB Nasional selama ini

telah berhasil mendorong peningkatan

peran serta masyarakat dalam membangun

keluarga kecil yang makin mandiri.

Keberhasilan ini mutlak harus diperhatikan

bahkan terus ditingkatkan karena

pencapaian tersebut belum merata. Bila

dilihat dari cara pemakaian alat kontasepsi dapat dikatakan bahwa 49,38\% akseptor

KB memilih Suntikan sebagai alat

kontrasepsi, 26,79 \% memilih Pil, 8,32\%

memilih Implant 7,39 \% memilih Intra

Uterine Devices (IUD), 1,56 \% memilih

Medis Operatif Wanita (MOW) dan 0,26

memilih Medis Operatif Pria (MOP),

(www. Bkkbn.go.id, 2010). Hingga

Desember 2010, total peserta KB aktif di

Jawa Timur sebanyak 6.150 .153 orang 
atau $126,46 \%$, dari 6.150 .153 peserta $\mathrm{KB}$ aktif, pengguna $\mathrm{KB}$ suntik sebanyak $48,2 \%$, pil $21,0 \%$, IUD atau spiral $14 \%$, Implan 8,5\%, medis operatif wanita 5\%, medis operatif pria $0,4 \%$. Sementara pengguna kondom 1,5\%. Pada umumnya masyarakat memilih metode non Metode Kontrasepsi Jangka Panjang (MKJP), sehingga metode KB MKJP seperti IUD, Implant, MOP dan MOW kurang diminati (www. bkkbn. go. id, 2010).

Salah satu masalah utama yang dihadapi saat ini adalah masih rendahnya penggunaan KB IUD, sedangkan kecenderungan penggunaan jenis $\mathrm{KB}$ hormonal seperti pil dan suntik jumlahnya terus meningkat tajam. Perlu dipertimbangkan bahwa sifat khas kontrasepsi hormonal dengan komponen hormon estrogen menyebabkan pemakainya mudah tersinggung, tegang, retensi air dan garam, berat badan bertambah, menimbulkan nyeri kepala, perdarahan banyak saat menstruasi, meningkatkan pengeluaran leukorea, menimbulkan perlunakan servik, sedangkan dengan komponen hormon progesteron menyebabkan payudara tegang, akne (kukulan), kulit beserta rambut kering, menstruasi berkurang, kaki serta tangan sering kram, dan liang senggama kering. Disamping itu pemakaian KB hormonal (pil KB) tidak dianjurkan pada akseptor yang memiliki penyakit hati, kencing manis, gangguan mental.

Penelitian terhadap kontrasepsi IUD sampai saat ini belum menunjukan hasil yang maksimal, kurangnya dukungan dari para tokoh tentang IUD, yang seharusnya dapat dijadikan sebagai contoh bagi sebagian masyarakat mengenai keberhasilannya, beberapa faktor lain yang diduga ikut mempengaruhi rendahnya penggunaan KB IUD diantaranya adalah ekonomi yang relatif masih rendah (keterjangkauan harga), pengetahuan mengenai alat kontrasepsi yang kurang, sikap yang tertutup dan kuranggnya 
motivasi dari keluarga serta tenaga kesehatan (BKKBN, 2006).

\section{METODE}

Desain dalam penelitian ini yang digunakan adalah deskriptif yaitu bertujuan untuk menggambarkan secara sistematis, aktual dan akurat mengenai faktor- faktor penghambat Akseptor $\mathrm{KB}$ dalam menentukan pilihan terhadap penggunaan alat kontrasepsi $I U D$ di Desa Kepunten Kecamatan Tulangan Sidoarjo. Waktu penelitian ini dilaksanakan pada bulan September 2011. Pada penelitian ini populasinya adalah semua akseptor $\mathrm{KB}$ non IUD di desa Kepunten Kecamatan Tulangan Sidoarjo periode bulan Juli sampai Agustus 2011 berjumlah 640 akseptor(akseptor aktif dan baru) rata-rata perbulan 45 akseptor. Jumlah Pasangan Usia Subur (PUS) di Desa Kepunten sebanyak 737 pasangan usia subur. Data dianalisis dengan menggunakan statistik deskriptif persentase.

\section{HASIL PENELITIAN}

Faktor-faktor yang menghambat Akseptor KB dalam memilih penggunaan alat kontrasepsi IUD adalah:

Biaya sebagai faktor penghambat akseptor KB memilih IUD sebesar $60 \%$ mengatakan biaya mahal yang menyebabkan mereka kurang berminat dalam menggunakan IUD sebagai kontrasepsi. Fenomena ini juga didukung oleh sebagian besar 17 responden (57\%) ibu tidak bekerja, sehingga mereka lebih memperhatikan angggaran harian mereka. Menurut Braham (2007) Faktor biaya mempengaruhi dimana suatu metode yang diinginkan membutuhkan biaya besar hanya satu kali pemakaian atau serangkaian biaya ringan tetapi bisa dilakukan selama beberapa waktu. Sebenarnya untuk biaya yang mahal tidak perlu dipermasalahkan lagi. Dalam hal ini pemerintah sudah memfasilitasi dengan jampersal. Di dalam jaminan persalinan tersebut ibu-ibu nifas ( ibu setelah melahirkan sampai 42 hari setelah melahirkan ) mendapatkan jaminan untuk 
memakai kontrasepsi yang biayanya sudah di tanggung oleh pemerintah, namun hal ini harus ditegakkan kembali oleh pelaksana pemasangan IUD yang bisa dilakukan oleh Bidan maupun tenaga kesehatan yang sudah terlatih tentang gratisnya kontrasepsi IUD. Dalam hal ini mereka yang bertanggung jawab dalam masalah ini. Mereka bisa memberikan konseling maupun mensosialisasikan kepada masyarakat, sehingga masyarakat bisa menggunakan kontrasepsi IUD tanpa harus dibebani dengan biaya yang mahal.

\section{Kurangnya dukungan suami} sebagai faktor penghambat akseptor $\mathrm{KB}$ memilih. permasalahan suami yang tidak mendukung, dikarenakan suami tidak selalu dilibatkan dalam konseling pemilihan kontrasepsi, sehinggga suami tidak ikut perperan aktif dalam pengambilan keputusan. Biasanya suami juga enggan masuk dan mendampingi istri dalam konseling pemilihan kontrasepsi. Dengan suami mendampingi istri dalam konseling KB akan memberikan dampak yang positif dan memberikan hasil yang maksimal. Dengan pemahaman suami tantang kontrasepsi IUD tentunya suami akan mendukung istrinya untuk menggunakan IUD, karena IUD merupakan kontrasepsi MKET yang menjadi primadona BKKBN, tidak mengandung hormon, dan efektif bisa digunakan dalam jangka waktu yang lama. Selanjutnya pemahaman suami yang salah, seperti pemasangan IUD dapat mengganggu saat berhubungan, merasakan sakit saat berhubungan itu dapat berkurang bahkan bergeser menjadi sebuah motivasi kepada istri untuk menggunakan kontrasepsi IUD Pemahaman terhadap IUD sebagai faktor penghambat akseptor KB memilih IUD sebesar 57\% sudah mengerti.

Jumlah anak sebagai faktor penghambat akseptor KB memilih IUD besar $10 \%$ jumlah anak banyak. Pada penelitian ini terdapat 19 responden (63\%) mempunyai 2-4 anak, dimana faktor usia mereka rata-rata usia 30 tahun, hal ini 
dirasa mereka masih merasa mampu untuk bereproduksi. Hal tersebut yang membuat mereka lebih memilih alat kontrasepsi suntik, karena menurut mereka lebih mudah dilepaskan setiap saat.

Takut terhadap alat-alat
pemasangan IUD sebagai faktor
penghambat akseptor KBmemilih IUD
besar $80 \%$ merasa takut. Perasaan takut
yang timbul biasanya disebabkan oleh
alat-alat yang digunakan dalam
pemasangan IUD. Apabila mereka sudah
memahami, maka sadar bahwa alat-alat
yang digunakan tidak membahayakan

DAFTAR PUSTAKA

Anggraini, Yetti. (2012). Pelayanan

Keluarga Berencana. Yogyakarta : Rohima Press

Azwar, Saifuddin. (2007). Sikap

Manusia. Yogyakarta: Pustaka Pelajar.

Brahm. (2007). Ragam Metode Kontrasepsi. Jakarta : EGC. dan tidak menakutkan lagi meskipun masih dirasakan sedikit sakit dalam pemasangan, namun hal ini masih dalam batas kewajaran, sehingga mereka sadar pemakaian alat tersebut sangat penting karena untuk mengetahui kondisi calon akseptor memenuhi syarat atau tidak untuk dilakukan pemasangan IUD.

Masalah pada pemasangan
IUD yang lalu sebagai faktor
penghambat akseptor KB memilih
IUD $100 \%$ tidak pernah mengalami
kegagalan.

Budiman. (2013). Kapita Selekta Kuesioner : Pengetahuan Dan Sikap Dalam Penelitian. Jakarta : Salemba Medika.

Everett, Suzanne. (2008). Buku Saku Kontrasepsi Dan Kesehatan Seksual. Jakarta : Egc 
Handayani, Sri. (2010). Buku Ajar

Pelayanan Keluarga Berencana.

Yogyakarta : Pustaka Rihama

Hidayat, A.A. (2007). Metode

Penelitian Kebidanan Dan Teknik Analisa

Data. Jakarta : Salemba Medika

Http://jurnalbidandiah.blogspot.co

$\underline{\mathrm{m} / 2012 / 02 / \mathrm{arti}-}$

kata.html\#ixzz2O5SZF19B,

diakses

tanggal 20 Februari 2012 Pukul 14.50

WIB.

Manuaba. (2010). Ilmu Kebidanan,

Penyakit Kandungan, Dan Kb Untuk

Pendidikan Bidan. Jakarta : ECG

Manuaba, (2009). Memahami

Kesehatan Reproduksi Wanita. Jakarta :

ECG
Meilani, Niken. (2010). Pelayanan

Keluarga Berencana. Jakarta :

FiramayaReproduktif. Jakarta : EGC

Notoatmodjo, Soekidjo. (2010).

Metodologi Penelitian Kesehatan. Jakarta :

Rineka Cipta

Prawirohardjo, Sarwono. (2011).

Ilmu Kandungan . Jakarta : PT Bina

Pustaka

Sulistyawati, Ari. (2011).

Pelayanan Keluarga Berencana. Jakarta :

Salemba Medika 